\title{
Susceptible Hosts: a Resort for Parasites Right in the Eye of the Immune Response*
}

\author{
GEORGE A. DOSREIS** \\ Laboratório de Biologia Imunitária, Instituto de Biofísica Carlos Chagas Filho, \\ Federal University of Rio de Janeiro, Cidade Universitária, \\ Ilha do Fundão - 21944-970 Rio de Janeiro, Brasil \\ Manuscript received on November 29, 1999; accepted for publication on December 8, 1999.

\begin{abstract}
Trypanosomatid protozoan parasites express an aggressive strategy of parasitism by infecting host macrophages and inducing extensive T-lymphocyte activation. One goal of such strategy is to drive the immune response of genetically susceptible hosts to a state of unresponsiveness regarding parasite killing. Unresponsiveness is achieved through different mechanisms, depending on the parasite species. In this brief review, recent findings on the molecular and cellular bases of the parasites' exploitation of host immune responses are discussed.
\end{abstract}

Key words: Trypanosoma cruzi, Leishmania chagasi, T lymphocytes, CTLA-4, apoptosis, transforming growth factor.

Trypanosomatid protozoan parasites, such as Trypanosoma cruzi (the agent of Chagas disease) and Leishmania chagasi (the agent of Visceral Leishmaniasis, or kalazar in the New World), induce chronic infection and consequent disease in genetically susceptible hosts, that can persist for life if left untreated. Persistence of intracellular pathogens must be associated with efficient mechanisms of immune evasion, since they mobilize intense innate and acquired immune responses in the infected hosts (DosReis 1997). However, the nature of genetic differences between resistant and susceptible hosts, and how these differences are exploited by parasites, remain to be defined. Previous studies demonstrated a deleterious role for the suppressive cytokine Transforming Growth Factor (TGF-) beta in infection of

*Invited paper

$* *$ Member of the Academia Brasileira de Ciências

E-mail: gdosreis@biof.ufrj.br susceptible mice with both T. cruzi (Silva et al. 1991) and L. chagasi (Wilson et al. 1998). In addition, TGF- $\beta$ plays a virulence-determinant role in murine infection by $L$. amazonensis and $L$. braziliensis, causative of cutaneous leishmaniasis (Barral-Netto et al. 1992). Currently, the nature of cellular immune mechanisms regulating TGF- $\beta$ secretion in infections by trypanosomatid parasites is unknown.

Working with a model of murine infection by T. cruzi, we demonstrated intense spontaneous lymphocyte apoptosis, and also activation-induced cell death (AICD) by apoptosis of $\mathrm{CD}^{+}{ }^{+} \mathrm{T}$ cells in the course of acute infection (Lopes et al. 1995), the first demonstration in a parasitic disease. The Fas-Fas Ligand (FasL) death pathway has been characterized as the major pathway for host $\mathrm{CD} 4^{+} \mathrm{T}$ cell apoptosis following vigorous immune responses (Van Parijs \& Abbas 1996). Fas is a surface receptor that 
expresses a caspase-activating death domain in its cytoplasmic tail, and belongs to the TNF Receptor Superfamily (Baker \& Reddy 1998). FasL is surface protein trimer induced in the cell membrane following T-cell activation through the T-cell receptor for antigen (TCR) (Van Parijs \& Abbas 1996). FasL is a member of the TNF superfamily (Baker \& Reddy 1998). We have characterized that Fas-FasL interactions mediate $\mathrm{CD}^{+} \mathrm{T}$ cell apoptosis that follows $T$. cruzi infection (Lopes et al. 1999). We have also investigated the pathogenic role of $\mathrm{CD} 4^{+} \mathrm{T}$ cell AICD in the control of $T$. cruzi replication within host macrophages $(\mathrm{M} \phi)$. The onset of $\mathrm{CD} 4^{+} \mathrm{T}$ cell AICD greatly exacerbates the growth of infective forms of T. cruzi within cocultured $\mathrm{M} \phi$ (Nunes et al. 1998). The deleterious effect was mediated by Fas-FasL interactions since: i) an agonist anti-Fas monoclonal antibody induced T-cell death and $T$. cruzi growth within $\mathrm{M} \phi$ (Nunes et al. 1998); ii) a neutralizing anti-FasL monoclonal antibody blocked both T-cell death and T. cruzi replication within $\mathrm{M} \phi$ (Nunes et al. 1998); iii) $\mathrm{CD}^{+} \mathrm{T}$ cells from infected, FasLmutant gld mice were unable to increase $T$. cruzi growth in wild-type M $\phi$ (Lopes et al. 1999). How do apoptotic lymphocytes exacerbate $T$. cruzi replication ? One intriguing possibility was that dead, but not alive $\mathrm{T}$ lymphocytes were partially responsible for the increased growth of the parasite. Uptake of apoptotic cells by $\mathrm{M} \phi$ triggers the autocrine and paracrine secretion of immunosuppressive mediators such as prostaglandin $\mathrm{E}_{2}\left(\mathrm{PGE}_{2}\right)$ and TGF$\beta$ (Fadok et al. 1998), that functionally inactivate $\mathrm{M} \phi$. Uptake of apoptotic cells by $\mathrm{M} \phi$ is mediated by a multifunctional receptor that includes CD36 and the integrin Vitronectin Receptor (VnR); the receptor binds thrombospondin attached to the apoptotic cells (Savill 1998). Based on these new concepts, we recently identified one mechanism driving the intracellular growth of $T$. cruzi in $\mathrm{M} \phi$. We found that apoptotic, but not necrotic or viable T cells, inactivate macrophages by blocking nitric oxide production, and exacerbate $T$. cruzi replication (Freirede-Lima et al. 2000). Adhesion of apoptotic cells to macrophages engages the $\mathrm{VnR}$, and $\mathrm{VnR}$ crosslinkage triggers intense $\mathrm{PGE}_{2}$ and subsequent TGF- $\beta$ production; TGF- $\beta$ secretion is required for parasite growth (Freire-de-Lima et al. 2000). Through engagement of VnR and autocrine TGF- $\beta$ secretion, apoptotic cells induce marked de novo ornithine decarboxylase (ODC) activity and polyamine (mainly putrescine) synthesis in $\mathrm{M} \phi$ (Freire-de-Lima et al. 2000). Parasitemia can be exacerbated in vivo by injection of apoptotic cells. Interestingly, blockers of polyamine synthesis inhibit $T$. cruzi growth induced by apoptotic cells in vitro, suggesting that the parasite uses this source of putrescine to replicate inside $\mathrm{M} \phi$. Pharmacological blockers of $\mathrm{PGE}_{2}$ secretion also prevent parasite replication in vitro and control parasitemia in vivo (Freire-de-Lima et al. 2000), suggesting that the phenomenon is immunopathogenic for T. cruzi infection. Thus, the onset of host lymphocyte apoptosis is beneficial to the parasite, as it triggers intense TGF- $\beta$ secretion and therefore, polyamine synthesis by infected $\mathrm{M} \phi$, driving parasite growth.

In a second model of chronic parasitic disease, susceptible mice were infected with $L$. chagasi (a model of murine kalazar). In this disease, the splenic load of $L$. chagasi increases indefinitely, and local $\mathrm{CD} 4^{+} \mathrm{T}$ cells are unresponsive to mitogen or leishmanial antigen stimulation, but do not undergo AICD (Gomes et al. 1998). Recently, the negative costimulatory T-cell receptor CTLA-4 has been characterized as an important negative regulator of T-cell activation (Waterhouse et al. 1995). We found that antibody-mediated blockade of either CTLA-4 or its ligand B7-1, restored otherwise suppressed T-cell responses, increased IFN- $\gamma$ production, and promoted rapid killing of $L$. chagasi parasites within splenic M $\phi$ (Gomes et al. 1998). Although the mechanisms of CTLA-4 suppression of T-cell activation are still undefined, a recent study demonstrated that engagement of CTLA-4 promotes the production of TGF- $\beta$ by $\mathrm{CD} 4^{+}$T cells, while inhibiting the production of all other cytokines tested (Chen et al. 1998). We found that splenic CD4 ${ }^{+}$ 
T cells from kalazar secrete large amounts of TGF$\beta$ when stimulated by Leishmania antigen or mitogens, and that TGF- $\beta$ secretion can be abolished by CTLA-4 blockade (Gomes et al. 2000). Moreover, we demonstrated that CTLA-4 engagement suppresses T-cell IFN- $\gamma$ production and promotes $L$. chagasi growth in cocultured $\mathrm{M} \phi$ through secretion of TGF- $\beta$ (Gomes et al. 2000). These results suggest that $L$. chagasi infection induces host T cells to produce TGF- $\beta$ by driving them to a state of sustained CTLA-4 engagement. However, the cell types and mechanisms responsible for sustained CTLA-4 engagement in $\mathrm{T}$ cells from kalazar remain to be determined. If these results could be extended to human $\mathrm{T}$ cells, they would suggest a new immunotherapic strategy for treating patients with kalazar.

Therefore, in spite of using very distinct mechanisms, both trypanosomatid parasites induce TGF$\beta$ production following intense mobilization of the host immune system, and TGF- $\beta$ appears to be an essential factor for parasite survival and growth. Modulation of cell interaction molecules directly or indirectly responsible for subsequent TGF- $\beta$ release, such as Fas, VnR and CTLA-4, could help in the elimination of parasites from susceptible hosts.

\section{ACKNOWLEDGMENTS}

The author's cited work received financial support from PADCT/World Bank/CNPq, FINEP, PRONEX-MCT, CNPq, CAPES, FUJB-UFRJ and FAPERJ.

\section{REFERENCES}

BAKER SJ \& REDDY EP 1998. Modulation of life and death by the TNF receptor superfamily. Oncogene 17: 3261-3270.

Barral-Netto M, Barral A, Brownell CE, Skeiky YA, Ellingsworth LR, TwardziK DR \& Reed SG 1992. Transforming growth factor-beta in leishmanial infection: a parasite escape mechanism. Science 257: 545-548.
Chen W, JiN W \& Wahl S 1998. Engagement of cytotoxic $\mathrm{T}$ lymphocyte-associated antigen 4 (CTLA-4) induces transforming growth factor $\beta$ (TGF- $\beta$ ) production by murine $\mathrm{CD} 4^{+} \mathrm{T}$ cells. $J$ Exp Med 188: 1849-1857.

DosReIs GA 1997. Cell-mediated immunity in experimental Trypanosoma cruzi infection. Parasitol Today 13: $335-342$.

Fadok VA, Bratton DL, Konowal A, Freed PW, Westcott JY \& Henson PM 1998. Macrophages that have ingested apoptotic cells in vitro inhibit proinflammatory cytokine production through autocrine/paracrine mechanisms involving TGF- $\beta$, PGE-2 and PAF. J Clin Invest 101: 890-898.

Freire-de-Lima CG, Nascimento DO, Soares MBP, de Mello FG, Bozza PT, Castro-Faria-Neto HC, DosReIs GA \& LoPES MF 2000. Uptake of apoptotic cells drives the growth of a pathogenic trypanosome in macrophages. Nature 403: 199-203.

Gomes NA, Barreto-de-SouZa V, WiLson ME \& DosREIS GA 1998. Unresponsive CD4 ${ }^{+} \mathrm{T}$ cells from Leishmania chagasi-infected mice increase cytokine secretion and mediate parasite killing after blockade of the B7-1:CTLA-4 pathway. J Infect Dis 178: 1847-1851.

Gomes NA, Gattass CR, Barreto-De-Souza V, WiLsON ME \& DosReis GA 2000. Transforming growth factor- $\beta$ mediates CTLA-4 suppression of cellular immunity in murine kalazar J Immunol 164: 20012008.

Lopes MF, Veiga VF, Santos AR, Fonseca MEF \& DosReis GA 1995. Activation-induced CD4 ${ }^{+} \mathrm{T}$ cell death by apoptosis in experimental Chagas' disease. J Immunol 154: 744-752.

Lopes MF, Nunes MP, Henriques-Pons A, Giese NA, Morse III HC, Davidson W, AraúJo-Jorge TC \& DosReIs GA 1999. Increased susceptibility of Fas Ligand-deficient gld mice to Trypanosoma cruzi infection due to a Th2-biased host immune response. Eur J Immunol 29: 81-89.

Nunes MP, Andrade RM, Lopes MF \& DosReis GA 1998. Activation-induced T cell death exacerbates Trypanosoma cruzi replication in macrophages co- 
cultured with $\mathrm{CD} 4^{+} \mathrm{T}$ lymphocytes from infected hosts J Immunol 160: 1313-1319.

SAvill J 1998. Phagocytic docking without shocking. Nature 392: 442-443.

Silva JS, Twardzik DR \& Reed SG 1991. Regulation of Trypanosoma cruzi infection in vitro and in vivo by transforming growth factor beta (TGF- $\beta$ ). $J$ Exp Med 174: 539-545.

Van Pariss L \& Abbas AK 1996. Role of Fas-mediated cell death in the regulation of immune responses $\mathrm{Curr}$ Opinion Immunol 8: 355-361.
Waterhouse P, Penning JM, Timms E, Wakeham A, Shahinian A, Lee KP, Thompson CB, Griesser H \& MAK TW 1995. Lymphoproliferative disorders with early lethality in mice deficient in CTLA-4. Science 270: 985-988.

Wilson ME, Young BM, Davidson BL, Mente KA $\&$ McGowan SE 1998. The importance of TGF$\beta$ in murine visceral leishmaniasis J Immunol 161: 6148-6155. 